\title{
The 1951 Refugee Convention's Contingent Rights Framework AND ARTICLE 26 OF THE ICCPR: A Fundamental INCOMPATIBILITY?
}

\author{
Marina SHARPE
}

\begin{abstract}
This article addresses the relationship between two primary structural features of the 1951 Convention relating to the Status of Refugees-that many benefits under it accrue on the basis of a refugee's degree of attachment to his or her host state and that many rights under the convention are guaranteed to a refugee only to the extent that they are enjoyed by a particular reference group-and the 1966 International Covenant on Civil and Political Rights' article 26 equality guarantee. Specifically, it examines whether attachment contingencies and reference groups, when incorporated in the refugee laws of states party to the ICCPR, might run afoul of article 26.
\end{abstract}

\section{Résumé}

Cet article examine les liens dialectiques entre deux principes essentiels $d u$ régime général des réfugiés. Il s'agit du principe d'attachement et de groupe de référence prévus par la Convention de 1951 sur le Statut des réfugiés et de l'égalité devant la loi telle que garantie par l'article $26 d u$ Pacte international relatif aux droits civils et politiques de 1966 (PIRCP). L'étendue des droits garantis par le régime conventionnel dépend du degré d'attachement du réfugié à son pays d'accueil et de la reconnaissance de ces droits au groupe de référence. Plus précisément, l'article analyse les conflits potentiels entre les garanties offertes par le régime général du PIRCP et la réception du principe de contingence et de groupe de référence dans les droits nationaux des Etats parties.

\section{Introduction}

$\mathrm{T}$ his article addresses the relationship between two primary yet often overlooked structural features of the 1951 Convention relating to the Status of Refugees, ${ }^{1}$ on the one hand, and the 1966 International Covenant on Civil and Political Rights ${ }^{2}$ (ICCPR) article 26 equality guarantee, on the other. The first feature of the 1951 convention at issue is that many rights under it accrue on the basis of the refugee's degree of attachment to the host state. In other words, whether a refugee is entitled to certain rights under the convention depends on the nature of his or her stay in the country of asylum. The 1951 convention includes five types of presence in the host state: mere jurisdictional control, physical presence, lawful presence, lawful stay, and habitual residence. The second feature of the 1951 convention at issue is that many rights under it are guaranteed to refugees only to the extent that a particular reference group also enjoys the right in question. The convention includes three reference groups: aliens generally in the same circumstances, most-favoured foreigners, and citizens.

This article examines whether attachment contingencies and reference groups, when reflected in the domestic refugee legislation of states party to the ICCPR, might be inconsistent with that instrument's article 26 equality provision. It does not, however, attempt to apply ICCPR article 
26 equality analysis to the differential allocation of a particular right as between different groups of refugees, or to rights guaranteed to refugees at a standard lower than that enjoyed by nationals or other aliens, because such analysis is entirely dependent on particular facts: the right at issue and the nature of the unequal treatment suffered. Even if facts were invented for the sake of hypothetical analysis, the resulting conclusion would be no more than speculative because the Human Rights Committee (HRC) - the ICCPR treaty-monitoring body-has never applied article 26 scrutiny to a state party's domestic refugee law. What this article does do, however, is deconstruct the 1951 convention's system of attachment contingencies and reference groups, explain the scope of the ICCPR article 26 equality guarantee, and highlight that this guarantee applies to the 1951 convention system of attachment contingencies and reference groups when these are reflected in the refugee laws of states party to the ICCPR. This is with a view to encouraging refugee advocates to consider article 26 among the arsenal of legal arguments available for the advance of refugees' rights.

The article begins with a more detailed explanation of the 1951 convention's attachment criteria and its reference group approach, enumerating the rights subject to each contingency, and then demonstrating how certain rights are dually contingent. This is followed by an overview of ICCPR article 26 and the criteria set by the HRC to determine when differential allocations of rights run afoul of the provision. The article's fourth section then argues that the 1951 convention's reference group approach and its attachment criteria could each reasonably be found to be incompatible with ICCPR article 26 when such an approach and criteria are reflected in domestic laws. It also notes that the ICCPR's and the International Covenant on Economic, Social and Cultural

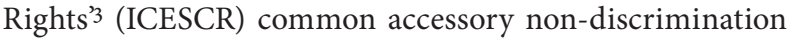
provision prohibits distinctions between refugees and nationals, and among refugees, in respect of rights also protected by one of the covenants. A concluding section briefly contemplates the systemic implications of the analysis for the 1951 convention and its domestic counterparts.

In should be noted at the outset that in developed countries, refugees are rarely accorded a particular package of rights based on the 1951 convention; refugee legislation in developed countries does not usually follow the 1951 convention's contingent rights framework. Canada's Immigration and Refugee Protection Act, ${ }^{4}$ for example, does not address refugee rights. Refugees' rights are protected in general by the Canadian Charter of Rights and Freedoms, ${ }^{5}$ which applies to every person in Canada, ${ }^{6}$ and certain rights and/or benefits are the subject of specific laws and/or policies, such as the Interim Federal Health Program in the case of medical care for asylum seekers and refugees recently resettled to
Canada. In some developing countries, by contrast, refugee legislation follows the 1951 convention's rights framework exactly. Ghana's Refugee Law, 1992 is an example. The act's rights framework mirrors the 1951 convention, providing simply that a "person granted refugee status in Ghana shall be entitled to the rights and be subject to the duties specified in (a) ... [the 1951 convention]; (b) the Protocol Relating to the Status of Refugees of 1967 ..., and (c) the Organisation of African Unity Convention Governing the Specific Aspects of Refugee Problems in Africa." 7 These three international instruments are then attached to the Ghanaian act as schedules. The issue this article addresses is salient only in states such as Ghana, which approach refugee rights in line with the 1951 convention.

It should be further noted that nothing in this article should be taken to suggest that a treaty can invalidate an earlier international instrument with which it is incompatible. In other words, the incompatibility between the 1951 convention and the ICCPR suggested here should not be taken to imply that ICCPR article 26 invalidates the 1951 convention's contingent rights framework. Nothing in international law suggests that such is possible. Moreover, the Vienna Convention on the Law of Treaties contains a framework for the resolution of such conflicts (though it is usually applied to conflicting bilateral instruments). ${ }^{8}$ Rather, this article is about the effect in ICCPR states parties of that instrument's article 26 on domestic refugee laws that follow the 1951 convention framework.

\section{The 1951 Convention}

The 1951 convention is the international treaty relating to qualification for and disqualification from refugee status, and to refugee rights. Unlike international human rights law, most rights under the 1951 convention are not universally guaranteed. While article 3 of the 1951 convention prohibits discrimination on the grounds of race, religion, and country of origin, and the convention's article 5 clarifies that nothing in it impairs any right granted by any other law, most 1951 convention rights are themselves dependent on the nature of the refugee's presence in the asylum state and on the standards of treatment enjoyed by other groups in the host state. Each of these two features of the convention is discussed in turn.

Hathaway explains that the 1951 convention's attachment criteria represent an attempt to make rights contingent upon the strength of the bond between a refugee and his or her host state. ${ }^{9} \mathrm{He}$ explains this "assimilative path": ${ }^{10}$ "While all refugees benefit from a number of core rights, additional entitlements accrue as a function of the nature and duration of the attachment to the asylum state.... Before any given rights can be claimed by a particular refugee, the nature 
Table 1: 1951 Convention rights categorized by attachment criterion

\begin{tabular}{|c|c|c|c|c|}
\hline [Subject to jurisdiction] & [Physical presence] & Lawful presence & Lawful stay & Habitual residence \\
\hline $\begin{array}{l}\text { Art } 3 \\
\text { non-discrimination }\end{array}$ & $\begin{array}{l}\text { Art } 4 \text { freedom of } \\
\text { religion }\end{array}$ & Art 18 self-employment & $\begin{array}{l}\text { Art } 15 \text { right of } \\
\text { association }\end{array}$ & $\begin{array}{l}\text { Art } 7(2) \text { exemption from } \\
\text { legislative reciprocity }\end{array}$ \\
\hline Art 13 property rights & $\begin{array}{l}\text { Art } 25 \text { administrative } \\
\text { assistance }\end{array}$ & $\begin{array}{l}\text { Art } 26 \text { freedom of } \\
\text { movement and } \\
\text { residence }\end{array}$ & $\begin{array}{l}\text { Art } 17 \text { wage } \\
\text { employment }\end{array}$ & $\begin{array}{l}\text { Art } 14 \text { artistic and } \\
\text { industrial property }\end{array}$ \\
\hline $\begin{array}{l}\text { Art } 16(1) \text { access to } \\
\text { courts }\end{array}$ & $\begin{array}{l}\text { Art } 27 \text { identity } \\
\text { documents }\end{array}$ & $\begin{array}{l}\text { Art } 32 \text { protection from } \\
\text { expulsion }\end{array}$ & $\begin{array}{l}\text { Art } 19 \text { liberal } \\
\text { professions }\end{array}$ & $\begin{array}{l}\text { Art } 16(2) \text { legal aid and } \\
\text { exemption from cautio } \\
\text { judicatum solvi }\end{array}$ \\
\hline Art 20 rationing & $\begin{array}{l}\text { Art } 31 \text { no penalization } \\
\text { for unlawful entry }\end{array}$ & & Art 21 housing & $\begin{array}{l}\text { Art } 17(2) \text { exemption } \\
\text { from labour market } \\
\text { restrictions }\end{array}$ \\
\hline Art 22 public education & & & Art 23 public relief & \\
\hline Art 29 fiscal charges & & & $\begin{array}{l}\text { Art } 24 \text { labour legislation } \\
\text { and social security }\end{array}$ & \\
\hline Art 33 non-refoulement & & & Art 28 travel document & \\
\hline Art 34 naturalization & & & & \\
\hline
\end{tabular}

of his or her attachment to the host state must therefore be defined. The structure of the attachment system is incremental: because the levels build on one another,... rights once acquired are retained for the duration of refugee status."11

Usually, a refugee will become subject to the host state's jurisdiction at the same time as he or she becomes physically present in, or enters, the country of asylum. However, one can think of exceptional instances in which jurisdictional control precedes entry. For example, Edward Snowden was arguably subject to Russian jurisdiction during the 40 days he spent in Sheremetyevo Airport before officially crossing the border there. Physical presence is established as soon as the refugee is within host state territory. The contours of "lawful presence" are less straightforward. Hathaway addresses them in depth.12 For the purposes of this article, it is sufficient to note that lawful presence certainly refers to "the stage between 'irregular' presence and the recognition or denial of refugee status, including the time required for any appeals or reviews." "Lawfully staying" is also complex; ${ }^{14}$ for our purposes, it suffices to note that lawful stay is characterised by "officially sanctioned, ongoing presence in a state party, whether or not there has been a formal declaration of refugee status, grant of the right of permanent residence, or establishment of domicile there."15 Habitual residence is generally achieved when the refugee has lived in the host state for a statutorily defined continuous period of time. ${ }^{16}$ In sum, "some rights apply simply once a state has jurisdiction over a refugee; others by virtue of physical presence in a state's territory, even if illegal; a third set when that presence is either officially sanctioned or tolerated; further rights accrue once the refugee has established more than a transient or interim presence in the asylum state; and even the most demanding
Table 2: Rights guaranteed to a standard below national treatment

Art 13 property rights

Art 15 right of association

Art 17 wage employment

Art 18 self-employment

Art 19 liberal professions

Art 21 housing

Art 22(2) public secondary education

Art 26 freedom of movement and residence

level of attachment requires only a period of de facto continuous and legally sanctioned residence."17

All 1951 convention rights are categorized according to their related attachment criteria in table $1{ }^{18}$ In the column headings, "Subject to jurisdiction" and "Physical presence" are bracketed because they represent a very low bar to the enjoyment of rights; indeed, it would be nonsensical to guarantee a right to a refugee not subject to host state jurisdiction. Nevertheless, they are included in the table in order to exhaustively deconstruct 1951 convention rights according to attachment criteria.

The 1951 convention's attachment criteria are the first of two ways in which most rights under that instrument are contingent. The second is its system of reference groups. Again, Hathaway's explanation is instructive. He notes that the standard for compliance with rights under the 1951 convention "varies as a function of the relevant treatment afforded another group under the laws and practices of the receiving country. Under these contingent rights standards, refugees are entitled to be assimilated either to nationals of 
Table 3: Dual contingencies on 1951 Convention rights

\begin{tabular}{|c|c|c|c|c|c|}
\hline & $\begin{array}{l}\text { [Subject to } \\
\text { jurisdiction] }\end{array}$ & $\begin{array}{l}\text { [Physical } \\
\text { presence] }\end{array}$ & Lawful presence & Lawful stay & Habitual residence \\
\hline \multirow{2}{*}{$\begin{array}{l}\text { Aliens generally } \\
\text { in the same } \\
\text { circumstances }\end{array}$} & $\begin{array}{l}\text { Art } 13 \text { property } \\
\text { rights }\end{array}$ & \multirow[t]{2}{*}{ - } & $\begin{array}{l}\text { Art } 18 \\
\text { self-employment }\end{array}$ & $\begin{array}{l}\text { Art } 19 \text { liberal } \\
\text { professions }\end{array}$ & \multirow[t]{2}{*}{-} \\
\hline & $\begin{array}{l}\text { Art 22(2) pub- } \\
\text { lic secondary } \\
\text { education }\end{array}$ & & $\begin{array}{l}\text { Art } 26 \text { freedom of } \\
\text { movement and } \\
\text { residence }\end{array}$ & Art 21 housing & \\
\hline \multirow[t]{2}{*}{$\begin{array}{l}\text { Most favoured } \\
\text { foreigners }\end{array}$} & - & \multirow[t]{2}{*}{ - } & - & $\begin{array}{l}\text { Art } 15 \text { right of } \\
\text { association }\end{array}$ & \multirow[t]{2}{*}{ - } \\
\hline & & & & $\begin{array}{l}\text { Art } 17 \text { wage } \\
\text { employment }\end{array}$ & \\
\hline \multirow[t]{4}{*}{ [Nationals] } & Art 20 rationing & \multirow{4}{*}{$\begin{array}{l}\text { Art } 4 \text { freedom of } \\
\text { religion } \\
\text { Art } 25(4) \text { fees for } \\
\text { administrative } \\
\text { assistance }\end{array}$} & \multirow[t]{4}{*}{-} & Art 23 public relief & \multirow{2}{*}{$\begin{array}{l}\text { Art } 14 \text { artistic } \\
\text { and industrial } \\
\text { property }\end{array}$} \\
\hline & $\begin{array}{l}\text { Art 22(1) public } \\
\text { elementary }\end{array}$ & & & \multirow{3}{*}{$\begin{array}{l}\text { Art } 24 \text { labour legis- } \\
\text { lation and social } \\
\text { security }\end{array}$} & \\
\hline & education & & & & \multirow{2}{*}{$\begin{array}{l}\text { Art } 16(2) \text { legal aid } \\
\text { and exemption } \\
\text { from cautio judi- } \\
\text { catum solvi }\end{array}$} \\
\hline & $\begin{array}{l}\text { Art } 29 \text { fiscal } \\
\text { charges }\end{array}$ & & & & \\
\hline
\end{tabular}

a most-favoured state, or to citizens of the asylum state itself. If no absolute or contingent standard is specified for a given right, refugees benefit from the usual standard of treatment applied to non-citizens present in the asylum state."19

This system "clearly presumes the legitimacy of treating refugees less favourably than citizens with respect to any of the rights defined by a contingent standard less than nationality."20 Those 1951 convention rights for which the reference group, and hence the standard of treatment, is below national treatment are listed in table 2.

Taken together, the 1951 convention's attachment criteria and its reference groups create a system of dual contingencies on certain refugee rights. Such rights are subject to both an attachment criterion and a reference group standard. This is represented in the contingency table (table 3). ${ }^{21}$ Each right in the table is subject to the attachment criterion in the column heading above it, and the same right is guaranteed only to the extent that the reference group named in the stub heading to the left also enjoys it. For example, under the 1951 convention, only refugees lawfully staying in the host state enjoy article 15 freedom of association, and the right is guaranteed to the standard enjoyed by the most favoured non-nationals in the host state. Again, "Subject to jurisdiction" and "Physical presence" are included for the sake of exhaustiveness; the brackets around these column headings indicate that these attachment criteria are a low bar to the enjoyment of rights. Similarly, national treatment is the highest standard of treatment and so does not represent a true contingency, as indicated by the brackets around it in the table; it is included for the sake of exhaustiveness.

When these reference groups and attachment criteria are incorporated into the domestic refugee laws of states party to the ICCPR, they may raise article 26 equality issues. This provision is discussed below.

\section{ICCPR Article 26}

A threshold consideration is whether the ICCPR applies to non-nationals, including refugees. The language of the ICCPR is such that its rights are generally owed to "everyone." Moreover, the HRC has clarified that "the general rule is that each one of the rights of the Covenant must be guaranteed without discrimination between citizens and aliens." ${ }^{22}$ Thus refugees in their host countries enjoy ICCPR rights.

The right at issue here is that to equality, which is given effect by states' duty of non-discrimination. The legal duty of non-discrimination requires that the treatment accorded to individuals not be based on their status, group membership, or irrelevant physical characteristics. ${ }^{23}$ Article 26 of ICCPR articulates this duty with particular force because the ambit of the guarantee is not limited to the ICCPR alone; ${ }^{24}$ rather, it applies to the "allocation of all public goods, including rights not stipulated by the Covenant itself." ${ }^{25}$ Nowak explains through an example: the ICCPR "contains no provision granting a right to sit on a park bench. But when a state party exacts a law forbidding Jews or blacks from sitting on public park benches, then this law violates Art. 26."26 Refugee rights are thus subject to ICCPR article $26,{ }^{27}$ rendering the international refugee convention as incorporated by ICCPR states parties justiciable by the HRC. ${ }^{28}$

ICCPR article 26 provides that "[a]ll persons are equal before the law and are entitled without any discrimination to the equal protection of the law. In this respect, the law shall prohibit any discrimination and guarantee to all 
persons equal and effective protection against discrimination on any ground such as race, colour, sex, language, religion, political or other opinion, national or social origin, property, birth or other status." 29

This guarantee ensures both formal equality (equality before the law) and substantive equality (equal protection of the law). Thus "refugees ... are entitled to invoke Art. 26 's duty to avoid arbitrary allocations and its affirmative duty to bring about non-arbitrary allocations."3o Article 26 does not, however, establish an unconditional right to equality, because not every instance of differential treatment amounts to discrimination. ${ }^{31}$ In many circumstances, it is perfectly reasonable for a state to differentiate between groups; affirmative action programs are the classic example. Rather, equality requires that any unequal treatment be "properly justified, according to consistently applied, persuasive, and acceptable criteria." 32 The classic statement of this principle was made by Justice Tanaka in his dissenting opinion in the South West Africa case. ${ }^{33}$ In the context of apartheid, Tanaka explained that differential treatment is permitted when it is just or reasonable, but justice and reasonableness always preclude arbitrary distinctions.

The HRC has accordingly read the following proviso into article 26: " $[\mathrm{N}]$ ot every differentiation of treatment will constitute discrimination, if the criteria for such differentiation are reasonable and objective and if the aim is to achieve a purpose which is legitimate under the Covenant." 34 Thus to amount to discrimination under ICCPR article 26 , unequal treatment must be based on criteria that are neither reasonable nor objective, nor in pursuit of a legitimate aim. Pobjoy has distilled this into a convenient three-pronged test for establishing unlawful discrimination:

1. Has there been differential treatment between individuals in similar circumstances? In other words, is there an inequality basis for a discrimination claim?

2. Is the unequal treatment based on a ground captured by art 26 ?

3. Is the unequal treatment based on "reasonable and objective" criteria? 35

The section that follows considers the impact of the 1951 convention's reference group approach and whether it can be reconciled with ICCPR article 26 .

\section{The 1951 Convention and ICCPR Article 26 4.1 The 1951 Convention's Reference Group Approach and ICCPR Article 26}

The 1951 convention's system of reference groups protects certain convention rights to a standard lower than that enjoyed by nationals and/or most-favoured foreigners. If this lesser treatment can be construed as resulting from refugees' status as such, then article 26 is invoked. The applicable prohibited ground of discrimination is "other status," which can be construed as including refugee status because the HRC generally interprets "other status" broadly, 36 and because it has understood the ground to include noncitizens. ${ }^{37}$ Indeed, Hathaway has noted that ICCPR article 26 might "be a sufficient basis to require asylum states to bring an end to any laws or practices that set refugees apart from the rest of their community." 38 To determine whether an instance of discrimination is saved by the HRC's proviso, one must apply Pobjoy's test to the right at issue.

There is, however, a more direct route to challenging below-national treatment than that provided by ICCPR article 26 , which has been highlighted by Hathaway. ${ }^{39}$ Both covenants include an accessory non-discrimination provision. Article 2(1) of the ICCPR provides that "[e] ach State Party to the present Covenant undertakes to respect and to ensure to all individuals within its territory and subject to its jurisdiction the rights recognized in the present Covenant, without distinction of any kind, such as race, colour, sex, language, religion, political or other opinion, national or social origin, property, birth or other status." Article 2(2) of the ICESCR provides substantively the same protection.

This article is subject to a similar proviso as ICCPR article 26: distinctions "are prohibited as discriminatory only when they are not supported by reasonable and objective criteria."40 Yet in general terms, article 2(1)/2(2) effectively precludes discrimination relative to citizens. ${ }^{41}$ It is accordingly "not necessary to rely on the relevant refugee right in order to contest treatment below national treatment. Since virtually all rights in the Covenants must be implemented without discrimination between nationals and non-citizens, refugees who invoke the cognate Covenant protection can effectively avoid the lower standard of treatment prescribed by the Refugee Convention."42 In respect of contingent 1951 convention rights also protected by the ICCPR or the ICESCR - article 15 on rights of association, article 17 on wage employment, article 18 on self-employment, article 21 on housing, article 22(2) on secondary education, and article 26 on freedom of movement and residence ${ }^{43}$-refugees are thus entitled to national treatment unless the state can establish that treating refugees differently from nationals is reasonable.

It should be noted, however, that the ICESCR permits that developing countries-where the majority of the world's refugees are found-"with due regard to human rights and their national economy, may determine to what extent they would guarantee the economic rights recognized in the present Covenant to non-nationals." 44 Recourse to the ICESCR to raise less than national treatment in respect of economic rights is therefore most likely to be successful in developed states (where, as mentioned above, refugee rights are not usually contingent). ${ }^{45}$ Moreover, ICESCR rights are 
not guaranteed on an absolute basis; the standard is one of progressive realization. ${ }^{46}$ Finally, and most importantly, non-citizens often face significant obstacles to the enjoyment of their rights, at international law as well as under municipal law. Detailing the jurisprudence in this regard is beyond the scope of this article, and others have in any case already conducted such work. ${ }^{47}$ It suffices to note here that any reliance on the covenants to raise less than national treatment to the national standard will have to overcome several hurdles: the limit placed on their common accessory non-discrimination provision, the allowances made by the ICESCR for developing countries in terms of both economic rights and in terms of the standard for implementation, and more generally, negative jurisprudential trends. At the very least, the covenants common accessory non-discrimination provision represents an additional avenue through which to challenge less than national treatment of refugees in respect of rights also protected by the ICCPR or the ICESCR. Indeed, the Committee on Economic, Social and Cultural Rights has explained that "the ground of nationality should not bar access to Covenant rights ... The Covenant rights apply to everyone including non-nationals, such as refugees, asylum seekers." 48

In respect of those contingent 1951 convention rights found in neither the ICCPR nor the ICESCR - the rights to property (article 13) and to the practice of liberal professions (article 19) - the only approach to challenging less than national treatment is to subject the right at issue to Pobjoy's test to determine whether distinction between refugees and nationals might impugn ICCPR article 26, the critical third prong of which employs the HRC's proviso and asks whether less than national treatment can be said to be "reasonable and objective." The results of the analysis will differ depending on the host country and right at issue; 49 in the context of scarce resources, restricting socio-economic rights would likely be more easily justified than limiting civil and political rights. For example, in the context of scarce resources, it may be "reasonable and objective" to protect the local labour market by prohibiting refugees from practising their professions. Discrimination in the protection of property rights, by contrast, would probably be less easily saved.

Hathaway has noted three jurisprudential trends suggesting that the HRC might be reluctant to find distinctions between non-nationals and citizens unreasonable. First, the HRC "has too frequently been prepared to recognize differentiation on the basis of certain categories, including non-citizenship, as presumptively reasonable. Second and related, the Committee has paid insufficient attention to evidence that generally applicable standards may impact differently on differently situated groups ... third and most generally, the ... [HRC] routinely affords governments an extraordinarily broad margin of appreciation."50
He concludes by noting that "non-discrimination law has not yet evolved to the point that refugees and other noncitizens can safely assume that it will provide a sufficient answer to the failure to grant them rights on par with citizens." 51

This is not to say that the HRC has never referred to article 26 in connection with non-citizens. In its 2003 Concluding Observations on Latvia, the HRC expressed "its concern over the perpetuation of a situation of exclusion, resulting in lack of effective enjoyment of many Covenant rights by the non-citizen segment of the population, including political rights, the possibility to occupy certain State and public positions, the possibility to exercise certain professions in the private sector, restrictions in the area of ownership of agricultural land, as well as social benefits (art. 26)."52

Regarding refugees specifically, in its Concluding Observations on Germany, the HRC "warned that antiterrorism measures might create an 'atmosphere of latent suspicion' towards foreigners, in particular asylum-seekers, and referred to Article 26 in support of its observations." 53 The HRC has never, however, applied article 26 scrutiny to a refugee law's system of reference groups. Thus the current moment can most accurately be characterised "as one of legal uncertainty ... until and unless the ... [HRC] assesses the propriety of categorical differentiation based on citizenship ... it will be difficult to know which forms of exclusion are likely to be found valid, and which are in breach of Art. 26."54

\subsection{The 1951 Convention's Attachment Criteria and ICCPR Article 26}

As a result of the 1951 convention's system of reference groups, refugees suffer differential treatment relative to citizens. The convention's attachment criteria, by contrast, distinguish among different groups of refugees. Hathaway notes that the 1951 convention's levels of attachment are also "subject to scrutiny under Art. 26 to ensure that the withholding of benefits from some refugees is justifiable." 55 Clark and Niessen have implied the same. ${ }^{56}$ Hathaway does not, however, pursue the point. Rather, his extensive analysis of discrimination among refugees is based on other criteria, such as refugees' countries of origin. ${ }^{57}$

To offend article 26 , whether a refugee is subject to host state jurisdiction, physically present, lawfully present, lawfully staying, or habitually resident would have to be found to fall within the provision's final enumerated ground on which discrimination is prohibited: "other status." Yet, as above, there is also a simpler solution. Because the covenants protect everyone on state territory, refugees who are merely physically present have the benefit of those 1951 convention rights that require lawful presence, stay, or habitual residence if such rights are also included in the ICCPR or, in some cases, in the ICESCR. In other words, certain 
rights weakly protected in international refugee law benefit from the complementarity of international human rights law. Accordingly, the 1951 convention's rights to artistic and industrial property (article 14), of association (article 15) and access to courts (article 16(2)), and to self- and wage employment (articles 17 and 18), housing (article 21), and labour legislation and social security (article 24), which under international refugee law are guaranteed only to those lawfully present, staying, or habitually resident, are by virtue of the ICCPR or ICESCR equally available to refugees physically present (and lawfully present, as applicable)..$^{8}$

Note, however, that the degree of protection accorded under the relevant covenant will, of course, depend on the particular right at issue. For example, intellectual property rights are protected only weakly under the ICESCR. 59 Moreover, as above, in developing countries the ICESCR article 2(3) caveat, and in general its standard of progressive realisation, applies to 1951 convention rights contingent upon lawful presence, stay, or habitual residence and also included in the ICESCR. More generally, the hurdles faced by non-citizens in the enjoyment of their rights apply equally in this context. ${ }^{60}$

For the remaining rights-those 1951 convention rights dependent on strong attachment, which as refugee-specific rights feature in neither the ICCPR nor the ICESCR, or more general rights subject to limitations under these instrumentsthe analysis to determine whether the 1951 convention's attachment criteria approach contravenes ICCPR article 26 is as above: by application of Pobjoy's test in context to differential allocations of rights as between different classes of refugees. The rights susceptible to such analysis are listed in table 4 .

On a normative basis at least, it has been argued that "while a State is exercising its jurisdiction over a person with respect to the determination of any one right, including the right to a status, the person should enjoy other rights to the extent possible." ${ }^{2}$ Whether the ICCPR article 26 analysis will suggest the same will depend on the right, how it has been differentially protected, and the particular host country situation at issue. The HRC has never assessed whether a domestic refugee law featuring attachment criteria offends article 26. However, it should be noted that in his analysis of discrimination among refugees (on grounds other than their degree of attachment to the host state), Hathaway finds that ICCPR article 26 "has considerable value as a complementary prohibition of discrimination between classes of refugees in the allocation of a wide-ranging set of rights." ${ }^{\prime 3}$

\section{Conclusion}

This short article has deconstructed the system of attachment criteria and reference groups that underlies the 1951 convention. It has also highlighted that the ICCPR's article
Table 4: 1951 Convention rights with strong attachment criteria (> physical presence) and no international human rights law complementarity

\begin{tabular}{l}
\hline Art 7(2) exemption from legislative reciprocity \\
\hline Art 19 liberal professions \\
Art 23 public relief \\
Art 26 freedom of movement (ICCPR art 12 requires the \\
person be "lawfully within" state party territory) ${ }^{61}$ \\
Art 28 travel document \\
Art 32 protection from expulsion (ICCPR art 13 requires \\
the person be "lawfully in" state party territory) \\
\hline
\end{tabular}

26 applies to domestic refugee laws based on this system in states party to the ICCPR. It is hoped that this will encourage refugee advocates to consider article 26 among the tools available to them to advance refugee rights. Furthermore, it has emphasized that in respect of 1951 convention rights that are also protected by one of the covenants, their common accessory non-discrimination provision can raise less than national standards of treatment to the national level, provided that the distinction at issue is neither reasonable nor objective. The covenants similarly protect refugees who are merely physically present from a lower standard of treatment than that accorded to more attached refugees.

On a more systemic level, this article has highlighted a particular instance of a fairly common issue on the international plane: treaties can be inconsistent with earlier international instruments. In this case, ICCPR article 26 is inconsistent with the international refugee convention that came before it. Certainly, if the ICCPR had existed when the 1951 convention was drafted and adopted, the latter would have emerged as a completely different instrument, likely without its facially discriminatory system of reference groups and attachment criteria. Today, there is only one route through which these facets of the 1951 convention might be challenged: via its article 38 , which allows disputes over the interpretation or application of the convention to be referred to the International Court of Justice (ICJ) by one of the parties to the dispute. Thus a state would have to view the 1951 convention's reference groups and/or attachment criteria as untenable in view of ICCPR article 26 , and would have to take the issue to the ICJ for resolution. However, it is unlikely that an article 38 referral would ever occur, nor would it be desirable. The convention's reference groups and attachment criteria underlie almost the entire instrument; invalidating them would virtually open the 1951 convention up for renegotiation, and in the current global climate any new refugee convention would surely be less generous than that adopted in 1951.

On the municipal plane, this article has highlighted the relationship between ICCPR article 26 and domestic refugee 
laws that follow the 1951 convention's rights framework. An interesting avenue for future research would be to examine what, if any, impact the ICCPR has had on national refugee laws adopted or amended after the state in question became party to the ICCPR. Uganda's 2006 Refugees Act, for example, features no attachment criteria and only one reference group: "aliens generally in similar circumstances." 64 Whether this was a result of the ICCPR is unclear, but Hansard and drafting committee records might be revealing in this regard.

Whatever the effect of the ICCPR, at the very least it represents a litigation tool. It may also be used as a shield rather than as a sword, to borrow the metaphor usually applied to estoppel. Given the current state of HRC and municipal jurisprudence on the rights of non-nationals, the real poten tial of ICCPR article 26 in respect of the contingencies on refugees' rights may lie in its potential as an interpretive tool to update our understanding of the 1951 convention. Under article 31(3)(c) of the Vienna Convention on the Law of Treaties, ${ }^{65}$ "relevant rules of international law applicable in the relations between the parties" are applicable in the interpretation of treaties. This expresses a more general principle of treaty interpretation: the systemic integration of the international legal system. ${ }^{66}$ According to this principle, states and courts, in interpreting and applying the 1951 convention (and perhaps domestic laws based on it), could consider ICCPR article 26 , as well as international human rights law more generally. ${ }^{67}$ It is hoped that such consideration will occur and that it will promote a generous interpretation of refugees' rights under the 1951 convention and its domestic equivalents.

\section{Notes}

1 Convention relating to the Status of Refugees, 28 July 1951, 189 UNTS 137, Can TS 1969 No 6 [1951 Convention].

2 International Covenant on Civil and Political Rights, 19 December 1966, 999 UNTS 171, Can TS 1976 No 47 [ICCPR].

3 International Covenant on Economic, Social and Cultural Rights, 16 December 1966, 993 UNTS 3, Can TS 1976 No 46 [ICESCR].

4 Immigration and Refugee Protection Act, RSC 2001, c 27.

5 Canadian Charter of Rights and Freedoms, Part I of the Constitution Act, 1982, being Schedule B to the Canada Act 1982 (UK), 1982, c 11.

6 See, however, Catherine Dauvergne, "How the Charter Has Failed Non-Citizens in Canada: Reviewing Thirty Years of Supreme Court of Canada Jurisprudence" (2013) 58 McGill LJ 663.

7 Refugee Law, 1992 (Ghana) PNDCL 305D, s 11.

8 Vienna Convention on the Law of Treaties, 23 May 1969,1155 UNTS 331 , Can TS 1980 No 37 [VCLT] art 30.
9 James Hathaway, The Rights of Refugees under International Law (Cambridge: Cambridge University Press, 2005) at 154 .

10 Ibid at 156.

11 Ibid at $154-5$.

12 Ibid at $173-86$.

13 Ibid at 175 .

14 Ibid at $186-90$.

15 Ibid at 189 .

16 See Hathaway, supra note 9 at 190-192.

17 Ibid at 192.

18 The host state's duties of non-discrimination (article 4) and non-refoulement (article 33) are not contingent.

19 Hathaway, supra note 9 at 155.

20 Ibid at 248.

21 This presentation and tables 1 and 2 above, which table 3 combines, is based largely on Hathaway's presentation in The Rights of Refugees under International Law, supra note 9. Other authors have offered slightly different presentations. See, for example, Vincent Chetail, "Are Refugee Rights Human Rights? An Unorthodox Questioning of the Relations between Refugee Law and Human Rights Law" in Ruth Rubio Marin eds, Migrations and Human Rights: Collected Courses of the Academy of European Law (Oxford: Oxford University Press, 2014).

22 HRCOR, 27th Sess, "General Comment No. 15: The Position of Aliens Under the Covenant" (11 April 1986) para 2.

23 Sandra Fredman, Discrimination Law (Oxford: Oxford University Press, 2011) at 109.

24 HRCOR, 37th Sess, "General Comment No. 18: Non-Discrimination” (11 October 1989) para 12.

25 Hathaway, supra note 9 at 125.

26 Manfred Nowak, UN Covenant on Civil and Political Rights: CCPR Commentary, 2nd ed (Kehl: NP Engel, 2005) at 605.

27 Tom Clark, "Rights Based Refuge, the Potential of the 1951 Convention and the Need for Authoritative Interpretation" (2004) 16 Int J Ref L 584 at 586.

28 Tom Clark and François Crépeau, "Mainstreaming Refugee Rights: The 1951 Refugee Convention and International Human Rights Law" (1999) 17 Nethl QHR 398 at 408.

29 ICCPR, supra note 2, art. 26.

30 Hathaway, supra note 9 at 127.

31 Fredman, supra note 23 at 8.

32 Christopher McCrudden, "Equality and Discrimination", in David Feldman ed, English Public Law (Oxford: Oxford University Press, 2004), cited in Hathaway, supra note 9 at 124.

33 South West Africa (Ethiopia v South Africa; Liberia v South Africa) [1966] ICJ Rep 6.

34 HRCOR, supra note 24, para 13.

35 Jason Pobjoy, "Treating Like Alike: The Principle of NonDiscrimination as a Tool to Mandate the Equal Treatment of Refugees and Beneficiaries of Complementary Protection" (2010) 34 Melbourne UL Rev 181 at 210.

36 Santhosh Persaud, "Protecting Refugees and Asylum Seekers under the International Covenant on Civil and 
Political Rights", New Issues in Refugee Research Paper No. 132 (November 2006), online: <http://www.refworld. $\mathrm{org} / \mathrm{pdfid} / 4 \mathrm{ff} 150762 . \mathrm{pdf}>$ at 22.

37 HRCOR, Ibrahima Gueye et al v France, Comm No 196/1985, [1989] UN Doc CCPR/C/35/D/196/1985 para 9.4; note that it is unlikely that the "national origin" ground covers non-nationals.

38 Hathaway, supra note 9 at 127-8.

39 Ibid at 249-50.

40 Nowak, supra note 26 at $45-6$.

41 Ibid at 249.

42 Ibid.

43 Freedom of movement and residence, which under the 1951 Convention require lawful presence, are included in the ICCPR, but under that instrument they are guaranteed only to everyone "lawfully within" the state. As the issue hhas never been adjudicated, it is unclear whether refugees physically present would qualify as being "lawfully within" the host state within the meaning of the ICCPR.

44 ICESCR, supra note 3, art 2(3).

45 Especially in light of the European Court of Human Rights decision in MSS $v$ Belgium and Greece (MSS v Belgium and Greece, Application No 30696/09 [Merits 21 January 2011]), which held that refugee hosting states must guarantee certain core economic rights, lest they violate the European Convention on Human Rights' prohibition of torture (Convention for the Protection of Human Rights and Fundamental Freedoms (European Convention on Human Rights, as amended) art 3).

46 ICESCR, supra note 3, art 2(1).

47 See generally, Alice Edwards and Carla Ferstman, eds., Human Security and Non-Citizens (Cambridge: Cambridge University Press, 2010); David Weissbrodt, The Human Rights of Non-Citizens (Oxford: Oxford University Press, 2008). For the Canadian context, see Dauvergne, supra note 6.

48 CESCROR, 42nd Sess, "General Comment No. 20: Nondiscrimination in Economic, Social and Cultural Rights (art 2, para 2, of the International Covenant on Economic, Social and Cultural Rights)", UN Doc E/C.12/GC/2O (2 July 2009) para 30.

49 Spencer and Pobjoy have conducted such analysis for the United Kingdom. See Sarah Spencer and Jason Pobjoy, "The Relationship between Immigration Status and Rights in the UK: Exploring the Rationale", Centre on Migration, Policy and Society Working Paper No 86 (2011), online: $<$ http://www.compas.ox.ac.uk/publications/working -papers/wp-11-86/>. Relevant in the Canadian context is Steve Sansom, "Refugee Claimants, OHIP Eligibility, and Equality” (1997) 12 J L \& Soc Pol'y 202.

50 Hathaway, supra note 9 at 129-30; for a summary of the case law, see Hathaway, supra note 9 at 124-47.

51 Ibid at 238 .

52 HRCOR, 79th, "Concluding Observations of the Human Rights Committee: Latvia” UN Doc. CCPR/CO/79/LVA (6
November 2003) para 18, cited in Persaud, supra note 36 at 23.

53 HRCOR, 8oth Sess, "Concluding Observations of the Human Rights Committee: Germany" UN Doc CCPR/ $\mathrm{CO} / 8 \mathrm{o} / \mathrm{DEU}$ (4 May 2004) para 20, cited in Persaud, supra note 36 at 23 .

54 Hathaway, supra note 9 at 133.

55 Ibid. at 251.

56 Tom Clark and Jan Niessen, "Equality Rights and NonCitizens in Europe and America: The Promise, the Practice and Some Remaining Issues" (1996) 14 Nethl QHR 245 at 267 .

57 See Hathaway, supra note 9, at 238-6o.

58 See supra note 43.

59 See Hathaway, supra note 9 at 839-40.

60 See supra note 47.

61 The contours of the contingency have been clearly articulated by the HRC: "In principle, citizens of a State are always lawfully within the territory of that State. The question whether an alien is 'lawfully' within the territory of a State is a matter governed by domestic law, which may subject the entry of an alien to the territory of a State to restrictions, provided they are in compliance with the State's international obligations. In that connection, the Committee has held that an alien who entered the State illegally, but whose status has been regularized, must be considered to be lawfully within the territory for the purposes of article 12. Once a person is lawfully within a State, any restrictions on his or her rights guaranteed by article 12, paragraphs 1 and 2, as well as any treatment different from that accorded to nationals, have to be justified under the rules provided for by article 12, paragraph 3" (HRCOR, 67th Sess, "General Comment 27: Freedom of Movement (Art 12)”, UN Doc CCPR/C/21/Rev. 1/Add. 9 (1999) para 4).

62 Clark and Niessen, supra note 56 at 267.

63 Hathaway, supra note 9 at 260.

64 See Marina Sharpe and Salima Namusobya, "Refugee Status Determination and the Rights of Recognized Refugees under Uganda's Refugees Act 2006" (2012) 24 Intl J Refugee L 561 at 566-7; Uganda ratified the ICCPR in 1995.

65 VCLT, supra note 8.

66 See Campbell McLachlan, "The Principle of Systemic Interpretation and Article 31(3)(c) of the Vienna Convention” (2005) 54 Intl \& Comp LQ 279; Gardiner, Treaty Interpretation, 2nd ed (Oxford: Oxford University Press, 2010) chap 7.

67 Assuming, of course, that the jurisdiction in question is an ICCPR state party.

Marina Sharpe is a DPhil candidate and Trudeau Scholar at the Faculty of Law, University of Oxford. The author is grateful for helpful comments received from two anonymous Refuge referees and for the support of the Trudeau Foundation. She may be contacted at marina.sharpe@law.ox.ac.uk. 
(C) Marina Sharpe, 2014. This open-access work is licensed under a Creative Commons Attribution-NonCommercial 4.0 International License, which permits use, reproduction and distribution in any medium for non-commercial purposes, provided the original author(s) are credited and the original publication in Refuge: Canada's Journal on Refugees is cited. 